\section{Titanium isotopes constrain a magmatic transition at the Hadean-Archean boundary in the Acasta Gneiss Complex}

\author{
Sarah M. Aarons ${ }^{1,2 *}$, Jesse R. Reimink ${ }^{3,4}$, Nicolas D. Greber ${ }^{5}$, Andy W. Heard ${ }^{1}$, \\ Zhe Zhang ${ }^{1}$, Nicolas Dauphas ${ }^{1}$
}

Plate subduction greatly influences the physical and chemical characteristics of Earth's surface and deep interior, yet the timing of its initiation is debated because of the paucity of exposed rocks from Earth's early history. We show that the titanium isotopic composition of orthogneisses from the Acasta Gneiss Complex spanning the Hadean to Eoarchean transition falls on two distinct magmatic differentiation trends. Hadean tonalitic gneisses show titanium isotopic compositions comparable to modern evolved tholeiitic magmas, formed by differentiation of dry parental magmas in plume settings. Younger Eoarchean granitoid gneisses have titanium isotopic compositions comparable to modern calc-alkaline magmas produced in convergent arcs. Our data therefore document a shift from tholeiitic- to calc-alkaline-style magmatism between 4.02 and 3.75 billion years $(\mathrm{Ga})$ in the Slave craton.

\section{INTRODUCTION}

Modern manifestations of plate tectonics, such as seafloor magnetic reversal records (1), are absent from much of Earth's geological record, and researchers must instead rely on indirect evidence to recognize the action of plate tectonics in the past. Arc magmatism that occurs at subduction zones is one of the hallmarks of modern plate tectonics (2-4). Therefore, geochemical comparisons between ancient rocks and modern arc-derived igneous rocks has been the focus of many studies aimed at understanding when Earth entered into a geodynamic regime involving subduction. Ancient subduction may have differed in many respects from present-day occurrences, so interpretation of the rock record can be difficult. For example, age estimates for the initiation of plate tectonics range from $\sim 0.85$ to $>4.2$ billion years $(\mathrm{Ga})(5-13)$, spanning more than two-thirds of Earth's history.

Modern calc-alkaline magmas are uniquely associated with subduction zone environments. Characteristic features of calc-alkaline magmas are their higher water contents, and both relative Fe depletion, and greater oxidation than magmas in other tectonic settings $(2,14-18)$. Tholeiitic magmas, on the other hand, are characterized by sharp $\mathrm{FeO}$ and $\mathrm{TiO}_{2}$ enrichments during early magmatic differentiation, followed by more protracted depletions in these elements $(2,15)$. The reason for the unique geochemical evolution of calcalkaline magmatic series relative to the tholeiitic series is primarily the water-rich and oxidized nature of their parental melts, which suppresses crystallization of plagioclase and tends to promote the early crystallization of oxides and their subsequent loss as cumulates (19). On the modern Earth, the above conditions are encountered almost exclusively near subduction zones, where oxidized and waterrich fluids from subducted oceanic crust flux-melt the overlying mantle and trigger arc magmatism.

\footnotetext{
'Origins Laboratory, Department of the Geophysical Sciences and Enrico Fermi Institute, The University of Chicago, Chicago, IL 60637, USA. ${ }^{2}$ Scripps Institution of Oceanography, University of California, San Diego, San Diego, CA 92037, USA. ${ }^{3}$ Earth and Planets Laboratory, Carnegie Institution for Science, Washington, DC 20015, USA. ${ }^{4}$ Department of Geosciences, Pennsylvania State University, University Park, PA 16802, USA. Institute for Geological Sciences, University of Bern, 3012 Bern, Switzerland. *Corresponding author.Email: smaarons@ucsd.edu
}

Ancient rocks are exceedingly rare, with $>3.6$-Ga outcrops representing only a few parts per million of Earth's exposed crust (20), and those that are preserved have often undergone multiple metamorphic events, each with the potential to chemically overprint primary magmatic signatures. This is true for Earth's oldest presently known rocks, found in the Acasta Gneiss Complex (AGC; Slave craton, Canada). These rocks have experienced multiphase metamorphism, deformation, and igneous intrusion, which has resulted in the partial obliteration of primary textures and possibly bulk compositions, so that inferring primary chemical compositions is somewhat complicated. Reimink et al. $(21,22)$ identified several rock units, most notably the 4.02-Ga Idì whaà (translates to "ancient times" in the language of the Tłicho people who are indigenous to this area) tonalite gneiss (ITG) and volumetrically dominant 3.6- to 2.9-Ga granitoid rocks within the AGC, whose bulk compositions point to a transition between $\sim 4.0$ and $3.6 \mathrm{Ga}$ from Fe-rich to Fe-poor rock series. The rocks from the ITG are a part of the AGC, and for the remainder of the text, we use younger AGC to denote granitoids younger than $\sim 3.9 \mathrm{Ga}$. A plausible interpretation for the difference between ITG and younger AGC rocks is that ITG rocks differentiated from a dry magma, while AGC granitoids differentiated from wet magmas produced by melting of hydrated basalt (21-23). Trace element and radiogenic isotope compositions of the AGC have indicated changes in the modes of crustal generation at $3.55 \mathrm{Ga}(22,24-27)$, including evidence of a transition from shallow to deep-seated melting as well as a shift in the melt source from Hadean protocrust to hydrated primitive mantle. The rocks from the AGC have experienced a complex history, which makes a straightforward interpretation of elemental compositions of ancient rocks difficult. The diagrams used for classifying rocks into calc-alkaline and tholeiitic series and for identifying Fe enrichments typically involve plotting the samples in $\mathrm{Mg} / \mathrm{FeO}_{\text {total }}$ versus $\mathrm{SiO}_{2}$ (28) or $\mathrm{Na}_{2} \mathrm{O}+\mathrm{K}_{2} \mathrm{O}-\mathrm{FeO}-\mathrm{MgO}$ (14) diagrams. Many of the elements used for classification are fluid mobile $(\mathrm{Mg}, \mathrm{K}$, and $\mathrm{Na}$ ), and a potential concern is that the protoliths of the Acasta granitoids were affected by fluid-rock interactions that modified the bulk chemical composition of the rocks. Given the amphibolite metamorphic grade of these rocks, disturbance of primary chemical signatures is likely, but difficult to discern. Characterizing the conditions of differentiation in the AGC therefore requires geochemical 
proxies with memory of the path taken to a given rock chemical composition. Stable isotopic proxies are ideally suited to tackle this problem.

Recent work has shown that Ti isotopes can distinguish between rocks that underwent magmatic differentiation along the calc-alkaline trend and those that fall on the intraplate tholeiitic trend (29-32). The ${ }^{49} \mathrm{Ti} /{ }^{47} \mathrm{Ti}$ isotopic ratio (reported in $\delta^{49} \mathrm{Ti}$ notation; the per mil deviation relative to the ${ }^{49} \mathrm{Ti} /{ }^{47} \mathrm{Ti}$ ratio of the OL-Ti reference material) increases with $\mathrm{SiO}_{2}$ content in both calc-alkaline and tholeiitic rocks (29-32), but with the latter showing a much more rapid increase in $\delta^{49} \mathrm{Ti}$ with $\mathrm{SiO}_{2}$. Titanium is highly fluid immobile and unlikely to be substantially mobilized by metamorphic disturbance. The isotopic composition of $\mathrm{Ti}$ can therefore provide clues on the crystallization of Fe-Ti oxides on the liquid line of descent, which is a function of the water content, oxygen fugacity, and the initial geochemical composition. Thus, whole-rock $\mathrm{Ti}$ isotopes provide a valuable tool for identifying processes governing igneous rock formation and even geodynamic setting back in time, even on samples that have been multiply metamorphosed and possibly metasomatized.

Iron isotopic ratios are also fractionated by magmatic differentiation, and ${ }^{56} \mathrm{Fe} /{ }^{54} \mathrm{Fe}$ ratios (reported as $\delta^{56} \mathrm{Fe}$, the per mil deviation relative to the ${ }^{56} \mathrm{Fe} /{ }^{54} \mathrm{Fe}$ ratio of the IRMM-014 reference material) can also potentially trace Fe-Ti oxide crystallization (fig. S1). Here, we present $\mathrm{Ti}$ and Fe isotopic compositions of a suite of crustal magmatic rock samples ranging in age from 4.02 to $<3.6 \mathrm{Ga}$ with the aim of better characterizing the transition of magmatism in the AGC. The iron isotope data show notable scatter and are not straightforward to interpret. These data are not discussed further below, but more details are provided in the Supplementary Materials.

\section{RESULTS}

We observe variations in the Ti isotopic composition of ITG and younger AGC sample rocks (Fig. 1B). We also present the development of a new $\mathrm{Ti}$ isotope proxy that allows us to parameterize the affinity of ancient, altered rocks for intraplate tholeiitic versus calcalkaline trends. In contrast to the indistinguishable evolution of $\mathrm{TiO}_{2}$ content with increasing $\mathrm{SiO}_{2}$ in the sample set analyzed (Fig. 1A), we find that the $\delta^{49} \mathrm{Ti}$ compositions of AGC samples fall on two distinct trends (Fig. 1B) that both show increasing $\delta^{49}$ Ti values, ranging from $\sim+0.08$ to $0.96 \%$, with increasing $\mathrm{SiO}_{2}$. Titanium isotope data for the 4.02-Ga ITG and younger $\leq 3.75-\mathrm{Ga}$ AGC granitoids appear to plot along different trajectories, the former comparable to modern intraplate tholeiites and the latter on the trend characteristic of calcalkaline differentiation (Fig. 1B). The $\delta^{56} \mathrm{Fe}$ values of the younger AGC span a range (from +0.03 to $+0.17 \%$ ), and $\delta^{56} \mathrm{Fe}$ values of the $4.02 \mathrm{Ga}$ tonalites show a slightly decreasing trend with $\mathrm{SiO}_{2}$ content (fig. S1A).

\section{DISCUSSION}

Given the complex history of the rocks from the AGC, we consider the effects of fluid-rock interaction and metamorphic disturbance on the $\mathrm{Ti}$ isotopic compositions observed here. Like other high-field strength elements (HFSEs), Ti is very insoluble in most fluids of geological relevance (33). The $\mathrm{TiO}_{2}$ content in schists does not change with increasing metamorphic grade (34), indicating little mobilization and redistribution of Ti by alteration processes such as metamorphism and water-rock interaction. Titanium and HFSEs can only
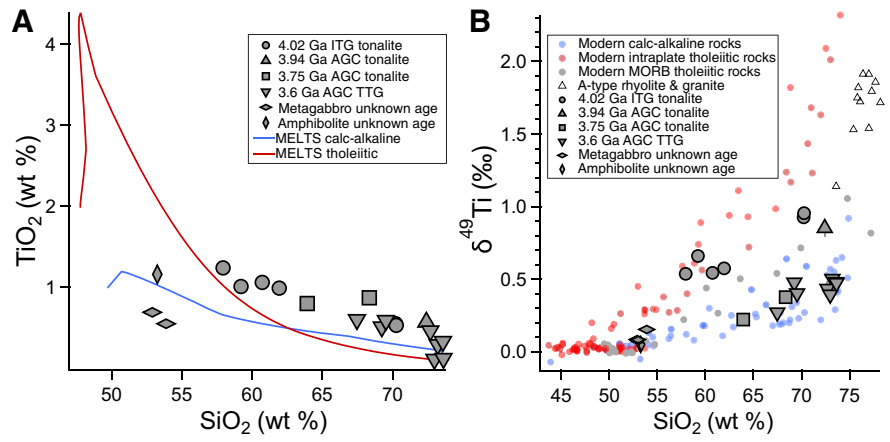

Fig. 1. Titanium geochemical and isotopic behavior during magmatic differentiation. $\mathrm{TiO}_{2}$ behavior $(\mathbf{A})$ and $\delta^{49} \mathrm{Ti}$ compositions (B) as functions of $\mathrm{SiO}_{2}$ content. Solid lines indicate MELTS model predictions during magmatic differentiation of a tholeiitic (red line) and calc-alkaline (blue line) melt (see the Supplementary Materials for details on MELTS modeling). Samples from the AGC are plotted as gray symbols in (A) and (B) (95\% confidence interval is smaller than symbol size). The $\delta^{49} \mathrm{Ti} \mathrm{com-}$ positions of rocks shown in (B) are from calc-alkaline (blue circles), intraplate tholeiitic (red circles), and modern MORB tholeiitic (gray circles) settings. The rock samples are Kos in the Aegean Arc (36), Agung volcano in the Sunda Arc (29), Santorini (32), Paleozoic granitoids (36), Archean TTGs (36), I- and S-type granitoids (36), Hekla/ Afar (30), Kîlauea Iki lava lake (31), Ko'olau (38), komatiites (49,51), Monowai (32), and MORB tholeiitic rocks from Alarcon Rise (gray circles). A-type granitoids (this study, white triangles; see table S1) from Lachlan Fold Belt in Australia and from Hailar basin (38) are shown. Note that volcanic rocks from Hailar basin (38) are not shown in (B) because of their complex formation mechanism.

be mobilized by localized alkalic, fluoride-bearing fluids (35) restricted to epithermal metal veins.

\section{$\mathrm{Ti}$ isotopes and the $\mathrm{Ti}$ isotope magmatic index}

Several geochemical metrics have been used to distinguish between calc-alkaline and tholeiitic magmas $(2,3,28)$, but they often rely on examining the behavior of $\mathrm{Fe}$ and $\mathrm{Mg}$ relative to $\mathrm{Si}$ or alkali elements. As discussed above, these classification schemes use fluid mobile elements like $\mathrm{K}, \mathrm{Na}$, and $\mathrm{Mg}$, which can be affected by fluid-rock interactions such as weathering or hydrothermal and metasomatic events. Furthermore, these schemes are most reliably used when the rocks sample a range of $\mathrm{SiO}_{2}$, a scarcity in the ancient rock record. Last, many of these diagrams tend to converge in the most evolved rocks, and the classification schemes are most useful when intermediate $\mathrm{SiO}_{2}$ rocks are available.

Titanium isotopes combined with major element compositions of rocks can be applied to overcome some of these problems and gauge the tholeiitic affinity of evolved rocks. We introduce a new empirical Ti isotope magmatic index (TIMI), which uses the relationship between the base 10 logarithm of the ratio between the $\mathrm{SiO}_{2}$ and $\mathrm{TiO}_{2}$ weight percentage $\log \left(\mathrm{SiO}_{2} / \mathrm{TiO}_{2}\right)$ and $\delta^{49} \mathrm{Ti}$ of rocks to define two distinct trends between tholeiitic rocks from Iceland, Afar hot spot, and Hawaii $(30,31)$ and calc-alkaline rocks from Agung and $\operatorname{Kos}(29,36)$ (Fig. 2A) that contain $>52$ weight \% (wt \%) $\mathrm{SiO}_{2}$ and are saturated in Fe-Ti oxides. The benefit of using $\log \left(\mathrm{SiO}_{2} / \mathrm{TiO}_{2}\right)$ versus $\delta^{49} \mathrm{Ti}$ is that the magmatic series define two distinct linear trends that can be fitted with a simple linear relationships (log is the base 10 logarithm, and $\mathrm{SiO}_{2}$ and $\mathrm{TiO}_{2}$ are concentrations in wt \%)

$$
\begin{gathered}
\text { Tholeiitic: } \delta^{49} \mathrm{Ti}=1.14 \log \frac{\mathrm{SiO}_{2}}{\mathrm{TiO}_{2}}-1.32 \\
\text { Calc-alkaline: } \delta^{49} \mathrm{Ti}=0.64 \log \frac{\mathrm{SiO}_{2}}{\mathrm{TiO}_{2}}-1.09
\end{gathered}
$$



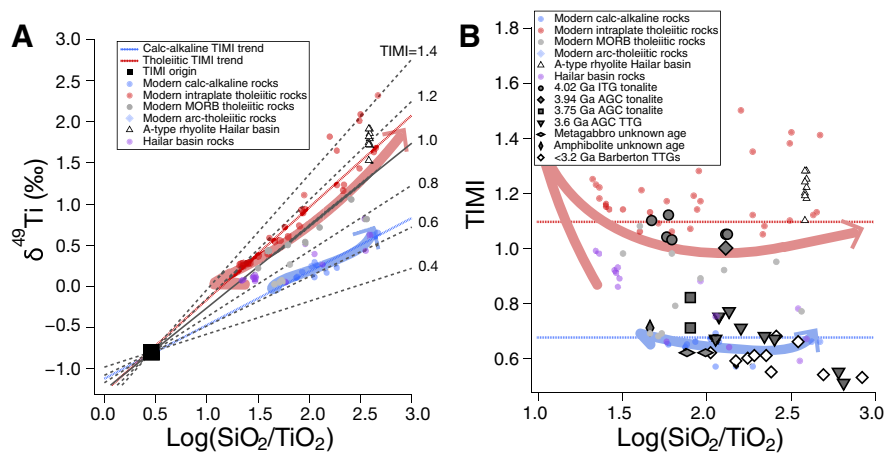

Fig. 2. Calculated TIMIs for modern calc-alkaline and tholeiitic rocks and rocks from AGC. (A) Relationship between $\delta^{49} \mathrm{Ti}$ and $\mathrm{Log}\left(\mathrm{SiO}_{2} / \mathrm{TiO}_{2}\right)$ for calc-alkaline rocks (blue circles) from Agung, Kos $(29,36)$, and Santorini $(32)$ and for intraplate tholeiitic rocks (red circles) from Hekla, Afar, and Hawaii $(24,25,38)$, Ascension, and Heard (32). Rocks from Alarcon Rise and Monowai (gray circles) (32), Hailar basin (purple circles) (38), AGC, and calc-alkaline and tholeiitic MELTS model output are shown. (B) Calculated TIMI for diverse igneous rocks. Published data from the $\sim 2.9$-Ga Barberton granitoids (36) define an average TIMI $=0.6$, similar to modern calc-alkaline rocks (TIMI $=0.64$ ). TIMIs of the 4.02-Ga ITG are $\sim 1.07$, similar to modern tholeiitic rock average $(\mathrm{TIMI}=1.15)$. Rocks dated between 4.0 and $3.6 \mathrm{Ga}$ have intermediate TIMIs (0.99), and AGC rocks younger than $3.94 \mathrm{Ga}$ average at 0.71 . Unknown age rocks (metagabbros and an amphibolite) have lower TIMI values suggesting calc-alkaline affinity. Blue and red dashed lines indicate first-order TIMI thresholds for calc-alkaline ( $\mathrm{TIMI} \leq 0.64$ ), sub-calc-alkaline ( $\mathrm{TIMI}=0.64$ to 1.15 ), and tholeiitic (TIMI $\geq 1.15$ ) rocks. Calc-alkaline and tholeiitic MELTS model output and calculations for TIMI (see Materials and Methods for details on MELTS modeling and Ti isotopic composition of MELTS output) are shown as schematic representations of the trajectories (colored arrows).

for intraplate tholeiitic and subduction-related calc-alkaline rocks, respectively (Fig. 2A). The linear correlations converge at $\log \left(\mathrm{SiO}_{2} /\right.$ $\left.\mathrm{TiO}_{2}\right)=0.46$ and $\delta^{49} \mathrm{Ti}=-0.80$. The slope (TIMI) of the segment between a rock and the convergence point, defined above, provides a measure of how tholeiitic a melt is. The slope defines an equation in the form

$$
\text { TIMI }=\frac{\delta^{49} \mathrm{Ti}+0.80}{\log \frac{\mathrm{SiO}_{2}}{\mathrm{TiO}_{2}}-0.46}
$$

The steeper the slope (higher TIMI), the more Fe-Ti oxides crystallized at low $\mathrm{SiO}_{2}$ concentration, which is one of the characteristics of tholeiitic magmatic differentiation. We use the classic subductionrelated calc-alkaline [Agung, Sunda Arc and Kos, Aegean $\operatorname{Arc}(29,36)$ ] and intraplate tholeiitic [Iceland, Afar, and Hawaii $(30,31)$ ] rocks to define TIMI, with an average TIMI value of 0.64 for calc-alkaline and 1.15 for intraplate tholeiitic rocks. Alkaline rocks from an intraplate setting [Ascension, Heard, and Afar (a different rock series than the tholeiitic described above; (32)] have TIMI values between 1.06 and 1.50 with an average of 1.24 , similar to tholeiitic intraplate rocks. Six of the seven analyzed rocks from the unique setting of Alarcon Rise specified as a mid-ocean ridge basalt (MORB) differentiation series have TIMIs between 0.89 and 1.08 (average of 0.97 ), similar to other tholeiitic rocks. Subduction-related samples from Santorini (Greece, Aegean Arc) that are calc-alkaline to mildly tholeiitic (37) and tholeiites from the Monowai seamount in the Tonga-Kermadec arc (32) have TIMIs from 0.68 to 0.88 (average of 0.77 ). One basalt $\left(\mathrm{SiO}_{2}=52 \mathrm{wt} \%\right.$ ) from Monowai with a TIMI of 0.57 has been excluded, as its $\delta^{49} \mathrm{Ti}$ composition of +0.01 indicates that the magma is undersaturated in
Fe-Ti oxides. The TIMI values from Monowai seamount are lower than dry intraplate tholeiitic rocks and higher than strongly calcalkaline rocks from Agung and Kos. Samples from the Hailar basin located in the Central Asian Orogenic Belt [China, (38)] that are complex, mixed melts of subduction-modified lithospheric mantle triggered by asthenosphere upwelling from the retreat of the paleoPacific trench (39) have TIMI values between 0.59 and 0.99 (average of 0.82). A-type rhyolites from the Hailar basin formed through melting of the continental crust have consistently high TIMI values of $>1.10$ (average of 1.22), identical to the A-type granites from the Lachlan Fold Belt analyzed here (see table S1).

In summary, TIMIs from subduction-related rocks are below 0.85 , with lower values signifying stronger calc-alkaline affinity. Tholeiitic and alkaline rocks from intraplate settings have TIMIs higher than 0.90 , and $85 \%$ of these are above 1.00 . Therefore, this index allows us to identify the calc-alkaline affinity of an individual evolved rock and the identification of rocks from intraplate or subduction origin. As an additional benefit, it only involves a major element $\left(\mathrm{SiO}_{2}\right)$ and an insoluble HFSE (Ti) and is therefore a robust method that should "see through" fluid-rock interaction. Silicification of rocks is a common feature in the Hadean and early Archean; however, the rocks studied here do not show evidence of silicification (26). Silica, which is a major component of igneous rocks, is quite immune to fluidrock interactions if obvious secondary quartz veins are avoided. Furthermore, small variations in $\mathrm{SiO}_{2}$ content do not substantially affect the TIMI. For example, a calc-alkaline rock sample (AGU25) from (29) has a TIMI of 0.66 at a $\mathrm{SiO}_{2}$ concentration of $65 \mathrm{wt} \%$. Even when strongly altering the $\mathrm{SiO}_{2}$ concentration of this sample to 55 or $75 \mathrm{wt} \%$ and altering the $\mathrm{TiO}_{2}$ concentration for the loss or gain of $\mathrm{SiO}_{2}$ results in a slightly modified TIMI of 0.72 and 0.61 , respectively.

Studies probing the fundamental differences in tholeiitic and calcalkaline magma series ascribe the timing and extent (with respect to $\mathrm{SiO}_{2}$ increase) of plagioclase and oxide crystallization as key controls on the behavior of Fe (and Ti) during magmatic differentiation $(15,40)$. The rate of plagioclase crystallization is important because, in the tholeiitic series, the dominance of plagioclase removal early on in crystallization passively enriches total $\mathrm{Fe}$ (and $\mathrm{Ti}$ ) contents, while $\mathrm{SiO}_{2}$ content of the melt remains approximately constant (15). By contrast, the presence of water and higher oxygen fugacity in the calc-alkaline magma series encourages early spinel and oxide crystallization and suppresses plagioclase crystallization, which drives the $\mathrm{SiO}_{2}$ content of the melt to higher values $(2,15)$. Because TIMI relies on the ratio of $\mathrm{SiO}_{2}$ to $\mathrm{TiO}_{2}$ and the $\delta^{49} \mathrm{Ti}$ composition of a rock, it isolates the controls of oxide (changes to $\mathrm{TiO}_{2}$ in melt) and plagioclase (changes to $\mathrm{SiO}_{2}$ in melt) saturation and fractionation during magmatic differentiation (Fig. 2B).

The relationship between $\delta^{49} \mathrm{Ti}$ and $\log \left(\mathrm{SiO}_{2} / \mathrm{TiO}_{2}\right)$ for samples from the AGC is shown in Fig. 2A. The 4.02-Ga ITG granitoids fall on a similar trend to that defined by modern tholeiitic rocks (mean TIMI ITG rocks $=1.07$ ), whereas the younger $\leq 3.75$-Ga AGC granitoids fall close to the trend defined by modern calc-alkaline rocks (mean TIMI AGC rocks = 0.71). Of note, rocks from $<3.2-\mathrm{Ga}$ Barberton TTG suite align with the modern calc-alkaline rock array as well (Fig. 2B). The observed switch in the TIMI value of AGC rocks suggests that, in this region, a change in the formation mechanism of granitoid rocks occurred at $3.8 \mathrm{Ga}$. Older samples were generated via tholeiitic magmatism, whereas younger samples were produced in a calc-alkaline magmatic setting, with the latter being the dominant type of granitoid formation since that transition. 


\section{A magma series transition at $\sim 3.8 \mathrm{Ga}$ in the Slave craton}

The clear compositional difference between the 4.02-Ga ITG and $\leq 3.75$-Ga AGC granitoids (Fig. 1A) in $\delta^{49} \mathrm{Ti}$ can provide insight into their formation mechanisms. The two distinct TIMI values of $\sim 1.07$ and $\sim 0.71$ of the ITG and AGC, respectively, compared to TIMI values of $\sim 1.15$ and $\sim 0.64$ for modern intraplate tholeiitic and calcalkaline rocks suggest the onset of hydrated, calc-alkaline-like magmatism and associated Fe-Ti oxide fractionation at around $3.8 \mathrm{Ga}$ (Fig. 3). In the younger magmatic differentiation regime, fractional crystallization occurred in a hydrated and potentially higher-pressure environment, which is consistent with existing petrological and geochemical data $(22,41)$. On modern Earth, nearly all calc-alkaline rocks are formed in magmatic arcs that overlie subductions zones. Therefore, a uniformitarian argument would suggest that the simplest explanation of our data is that a subduction-like setting existed on Earth at $3.75 \mathrm{Ga}$. However, there are notable major element differences between Archean TTGs and modern arc granitoids (42). These unique Archean TTG signatures can be explained by partial melting of a down-going slab, in contrast to the modern "dehydration-mantle wedge melting-magmatic differentiation" that typically produces arc granitoids. Our Ti isotope data alone cannot discriminate between these two processes, but as both require the downward transport of hydrated material to melting depths, the mechanisms that produced $\leq 3.75$-Ga TTGs in Acasta may have occurred in horizontal tectonic regime akin to subduction. The shift from dry magmatism, likely in a plume setting, to wet magmatism may be a short-lived regional occurrence, evidence of a pre-subduction regime (43-45), evidence for intermittent plate tectonics (an intermediate stage between plate tectonics and stagnant lid convection) $(43,46,47)$, or a true signature of modern-style convergent margin magmatism.

\section{Origin of the 4.02-Ga ITG through impact-induced melting or magmatic differentiation?}

In contrast to initial interpretations (21), recent work using phase equilibria modeling suggested that the 4.02-Ga ITG suite was produced via high-temperature partial melting of Fe-rich hydrated basalts at low pressures (48). Such low-pressure, high-temperature conditions were suggested to only be attainable at crustal conditions following meteorite impacts (48). Unlike fractional crystallization, single-stage equilibrium partial melting is not expected to produce large Ti isotopic fractionation because any distillation effect should be expressed in the residue rather than the melt $(29,36,49)$. The maximum isotopic

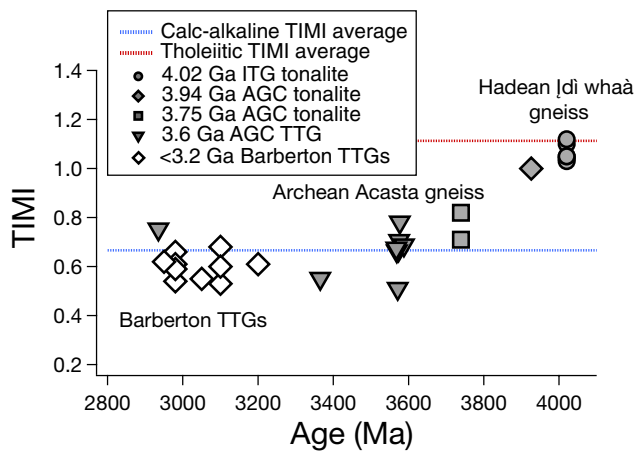

Fig. 3. Calculated TIMI for rocks from ITG and AGC (this study), same as in Fig. 2, and Barberton TTGs (36). Dashed red and blue lines show the average TIMI value for modern tholeiitic $(30,31)$ and calc-alkaline rocks $(29,36)$. fractionation will occur in a single stage during incipient melting and will most likely be small if equilibrium prevails [an assumption used in partial melting calculations (50)]. Any melt produced will, with greater melt fraction, progressively assume the isotopic composition of the starting material as more Ti is transferred to the melt.

To quantitatively test whether the ITG was formed via impactinduced single-stage partial melting event or during magmatic differentiation, we calculate the Ti isotopic composition of magma and cumulate minerals during partial melting and after the onset of Ti-bearing mineral crystallization using a Rayleigh distillation model approach (Fig. 4) $(29,51)$. At all steps, in the model for partial melting, we calculate the remaining Ti and the $\delta^{49} \mathrm{Ti}$ of the residual solid, instantaneous melt, and bulk melt. Likewise, for the fractional crystallization scenario, we calculate the remaining Ti and the $\delta^{49} \mathrm{Ti}$ of the melt, instantaneously formed crystals, and bulk cumulate (Fig. 4).

To assess the effects of partial melting of the crust, we follow the approach of (43), meaning that we assume that TTGs are the product of partial melting of basaltic protoliths and use average Ti isotopic compositions from 2.98-Ga TTGs from the Kaapvaal craton (31) and enriched MORBs as the source (49) (Fig. 4A). This approach uses the calculated abundance of Ti-bearing minerals at various melt fractions modeled at $0.1 \mathrm{GPa}$ used in trace element modeling of an impact melt event (48). We assume a Ti isotopic fractionation of $+0.344 \%$ between melt and residue, which is the fractionation factor between residue (E-MORB) and felsic melt (TTGs) (49). This Ti isotope fractionation factor between melt and solid residue is also consistent with that estimated using the method of (32), which is based on the correlation between $\mathrm{FeO} / \mathrm{TiO}_{2}$ and $\mathrm{SiO}_{2}$ concentrations (i.e., $~ 0.32 \%$ at $1000^{\circ} \mathrm{C}$ and $\sim 0.42 \%$ at $800^{\circ} \mathrm{C}$ ). For low-degree partial melting, the calculated Ti isotopic fractionation is, at most, $+0.34 \%$ (at negligible melt fraction), which is significantly lower than the $\delta^{49}$ Ti values of +0.54 to $+0.95 \%$ observed in the ITG samples. The heavy Ti isotopic values measured in ITG samples therefore provide evidence against the
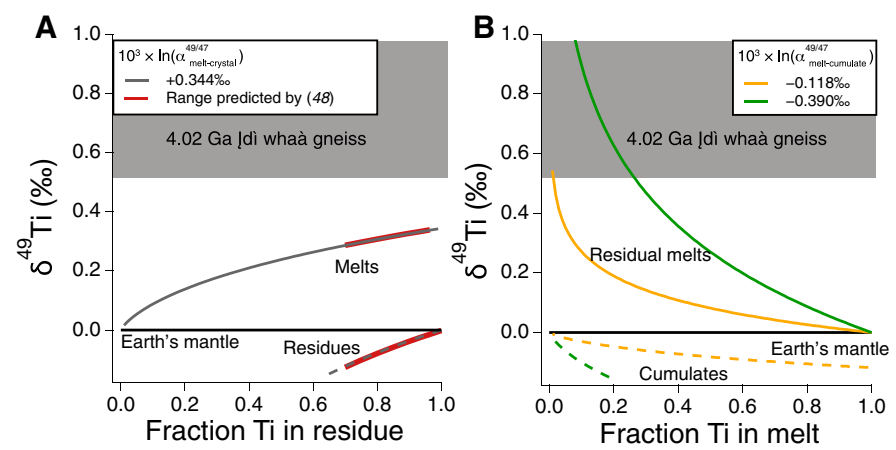

Fig. 4. Rayleigh distillation model of formation scenarios of the 4.02-Ga ldi whaà gneiss. (A) Partial melting of the mantle or basaltic crust scenario. The $\Delta^{49} \mathrm{Ti}_{\text {melt }}$ or residue-source was calculated using the Ti isotope data of depleted MORB mantle $(29,49)$ and TTG data from $(36)$ and assuming E-MORBs as source $(49)$. Range of $\delta^{49} \mathrm{Ti}$ predicted by partial melting of Ti-bearing minerals at $0.1 \mathrm{GPa}$ by (48) indicated by red lines. (B) Effect of Ti-bearing oxide crystallization on the evolution of magma and cumulate minerals. $\Delta^{49} \mathrm{Ti}_{\text {melt-cumulate }}$ was calculated following the approach of $(29,51)$ using $\Delta^{49} \mathrm{Ti}$ melt-ilmenite of $-0.118 \%$ o [at $T=1125^{\circ} \mathrm{C}$ (29)] and $-0.390 \%$ [at $T=1000^{\circ} \mathrm{C}(31)$ ]. Black line represents Earth's mantle composition (29), and gray shaded box represents the range of Ti isotopic compositions of ITG rocks (this study). The highest $\delta^{49} \mathrm{Ti}$ values of the ldì whaà gneiss cannot be explained by partial melting and are most likely due to fractional crystallization. 
formation of the ITG by impact-induced single-stage partial melting of the crust.

The elevated Ti isotopic compositions of the ITG are better explained by fractional crystallization. To model the Ti isotopic composition during fractional crystallization of Ti-bearing minerals from a magma, we follow the approach of $(29,51)$ using oxide melt $\mathrm{Ti}$ isotope fractionation factors from literature data $(29,31)$. The larger $\mathrm{Ti}$ isotopic fractionation produced during magmatic differentiation $\left(\delta^{49} \mathrm{Ti}\right.$ of residual melts varies from +0.00 to $+1.80 \%$ at $99 \%$ Ti removed from the melt) can achieve values consistent with the ones we see in the ITG, suggesting that the rocks from the ITG were likely produced through fractional crystallization and not impact-induced partial melting.

\section{Vertical versus lateral tectonics in the AGC}

The absence (or presence) of plate tectonics on Earth before $3.0 \mathrm{Ga}$ is currently debated in both geochemical and modeling studies. Notably, Archean TTGs have been suggested to be formed via intraplate sagduction. Sagduction may have occurred where magma from the base of an oceanic plateau becomes detached and sinks into the mantle, thereby melting to produce deep-seated TTGs. Recent work modeling the thermal evolution of Archean crust formation shows that sagduction fails to bring water and basaltic material to the great depths required to produce a large volume of felsic crust (52). Models are still capable of TTG production via intraplate sagduction, but they yield small felsic crustal volumes (53). Given the small geographic area of exposed crust at the AGC (fig. S3), it is possible that the calc-alkaline trend observed here is a by-product of sagduction. Other geodynamic models have shown that plume-induced subduction is a possible mechanism for initiating the first subduction zone before a globally active plate tectonic regime (50). Our Ti isotope data indicate the presence of calc-alkaline magmatism, which supports the notion that hydrated crust was transported to relatively great depths. This may indicate that subduction-like tectonic behavior could have initiated on at least a local scale, early in Earth history (54), or less likely that intraplate sagduction produced a small volume of felsic crust.

\section{MATERIALS AND METHODS \\ Samples}

To better understand the history of crystallization for the ITG and younger AGC granitoids, we have measured $\delta^{49} \mathrm{Ti}$ and $\delta^{56} \mathrm{Fe}$ values in rocks that span the Hadean-Archean transition at $4.0 \mathrm{Ga}$ (see the Supplementary Materials for analytical details). We report $20 \delta^{49} \mathrm{Ti}$ and $15 \delta^{56} \mathrm{Fe}$ compositions of individual rock samples (see table S1) from the AGC spanning in age from 4.02 to $<3.6 \mathrm{Ga}$ and ranging in silica content from metagabbro $\left(\mathrm{SiO}_{2}=52\right.$ to $\left.53 \mathrm{wt} \%\right)$ to tonalite $\left(\mathrm{SiO}_{2}=57\right.$ to $\left.72 \mathrm{wt} \%\right)$ to tonalite-trondhjemite-granodiorite $\left(\mathrm{SiO}_{2}=\right.$ 67 to 73 wt \%). We also report the Ti isotopic compositions of two A-type granites from the Lachlan Fold Belt, whose petrogenesis has been proposed to be the result of melting of meta-igneous granulite left behind from a previous melt extraction (55-57), melting of granulitic crust metasomatized by mantle derived fluids (58), differentiation of anhydrous magmas $(59,60)$, or partial melting of tonaliticgranodioritic rocks $(61,62)$. See the Supplementary Materials (fig. S1) for more discussion regarding A-type granite affinities.

Calc-alkaline and tholeiitic rocks have different behavior with respect to $\mathrm{TiO}_{2}$; tholeiitic rocks experience more pronounced $\mathrm{TiO}_{2}$ enrichment before saturation and crystallization of Fe-Ti oxides. Typically, the $\mathrm{TiO}_{2}$ content during magmatic differentiation can provide clues about the petrogenetic lineage of a sample; however, in the AGC samples, no differences are discernible (Fig. 1A). A likely reason for this is that all samples with robust zircon $\mathrm{U}-\mathrm{Pb}$ ages are differentiated beyond the onset of Fe-Ti oxide crystallization (> 55 wt \% $\mathrm{SiO}_{2}$ ), at which point the trends of the tholeiitic and calc-alkaline series tend to converge ( $>60$ wt $\% \mathrm{SiO}_{2}$; compare the red and blue curves in Fig. 1A). This convergence in composition illustrates the difficulty of ascribing a magma series grouping when rocks sampling a complete differentiation suite are not available.

\section{Methods}

Whole-rock samples used in this study have been extensively described in previous work $(21,23,26)$. Aliquots of the same sample powder were used here. Twenty bulk powder samples were prepared for Ti isotopic analysis following the methods described in (51), which involves alkali-flux fusion to ensure sample homogenization and complete dissolution of Ti before ion exchange chromatography. Following flux fusion, samples were digested and double-spiked with ${ }^{47} \mathrm{Ti}^{-}{ }^{49} \mathrm{Ti}$ solution in a fixed proportion to $\mathrm{Ti}$ in the sample. We use the double-spike technique to correct the data for mass bias introduced in the instrument (63). Titanium from the dissolved samples and geostandards was then purified using ion exchange chromatography following procedures described in (64). The Ti isotopic composition of each sample and geostandard was subsequently analyzed on a Neptune multi-collector inductively coupled plasma mass spectrometer (MC-ICPMS) at the University of Chicago in medium-resolution mode to resolve interferences of ${ }^{30} \mathrm{Si}^{16} \mathrm{O}$ on ${ }^{46} \mathrm{Ti}$ (63). The sample measurements were introduced in the instrument using an Aridus 1 desolvating nebulizer and bracketed by standard measurements with ${ }^{48} \mathrm{Ti}$ concentrations matched within $10 \%$ of the sample. Following a sample block of five samples, a clean acid solution was measured to correct for on-peak baseline. The samples were introduced in $0.3 \mathrm{M}$ nitric and $0.005 \mathrm{M}$ hydrofluoric acid. The Ti isotopic composition of each sample is reported in $\delta^{49} \mathrm{Ti}$ notation (see table S1), which is the per mil deviation of ${ }^{49} \mathrm{Ti} /{ }^{47} \mathrm{Ti}$ ratio of each sample relative to the Origins Laboratory Ti reference material (OL-Ti)

$$
\delta^{49} \mathrm{Ti}(\% 0)=\left(\frac{{ }^{49} \mathrm{Ti} /{ }^{47} \mathrm{Ti}_{\text {Sample }}}{{ }^{49} \mathrm{Ti} /{ }^{47} \mathrm{Ti}}-1\right) 1000
$$

The uncertainty on each measurement was evaluated according to (65) and encompasses both the measurement session and the long-term external reproducibility. The $\delta^{49} \mathrm{Ti}$ isotopic composition of each sample was calculated from the raw data by double-spike reduction using Mathematica following methods outlined in (63). All geostandards analyzed for Ti are reported in table S1 and agree with their recommended values.

The chemical digestion and separation procedure for Fe followed the methods outlined in (66). Weights of the sample powder aliquots ranged from 2 to $70 \mathrm{mg}$ for both geostandards and samples. After complete dissolution via acid digestion, the samples were purified using ion exchange chromatography. The Fe isotopic composition of each sample was then analyzed on a Neptune MC-ICPMS at the University of Chicago in medium-resolution mode to resolve interferences of $\mathrm{ArN}, \mathrm{ArO}$, and $\mathrm{ArOH}$. Instrumental mass fractionation was corrected for using standard-sample bracketing. Iron isotope 
variations are reported in $\delta^{56} \mathrm{Fe}$ notation, which is the per mil deviation of ${ }^{56} \mathrm{Fe} /{ }^{54} \mathrm{Fe}$ ratio of each sample relative to a reference material (IRMM-014)

$$
\delta^{56} \mathrm{Fe}(\%)=\left(\frac{{ }^{56} \mathrm{Fe} /{ }^{54} \mathrm{Fe}_{\text {Sample }}}{{ }^{56} \mathrm{Fe} /{ }^{54} \mathrm{Fe}_{\text {IRMM-014 }}}-1\right) 1000
$$

Precisions on $\delta^{56} \mathrm{Fe}$ are typically $\pm 0.03 \%$ ( $95 \%$ confidence interval) following nine standard-sample brackets. All geostandards analyzed are reported in table S2 and agree with their recommended values.

\section{TIMI applied to plutonic rocks}

The $\delta^{49} \mathrm{Ti}$ composition and $\log \left(\mathrm{SiO}_{2} / \mathrm{TiO}_{2}\right)$ relationship relative to the TIMI of modern tholeiitic, calc-alkaline, and various granitoid rocks are plotted in fig. S2. The $\delta^{49} \mathrm{Ti}$ composition of I- and S-type granites is from (36), and the A-type granites are data presented here. Previous studies have debated the petrogenesis of A-type granites, with hypotheses ranging from melting of anhydrous granulitic metaigneous residue left behind from a previous melt extraction (55-57), melting of granulitic crust metasomatized by mantle-derived fluids (58), differentiation of anhydrous magmas $(59,60)$, or partial melting of crustal tonalitic-granodioritic rocks $(56,57)$. On the basis of the TIMI thresholds defined for calc-alkaline (TIMI $\leq 0.64$ ), intermediate (TIMI $=0.64$ to 1.15$)$, and tholeiitic (TIMI $\geq 1.15)$ rocks, A-type granites display a tholeiitic affinity, whereas I- and S-type granites display a calc-alkaline affinity (fig. S2). On the basis of quantitative modeling of Ti isotopic compositions during partial melting and magmatic differentiation using a Rayleigh distillation model approach from $(29,51)$ (see main text; Fig. 4), it is likely that the A-type granites measured here formed via fractional crystallization of an anhydrous parental melt.

\section{MELTS modeling}

We performed Rhyolite-MELTS (63) modeling for a primitive tholeiitic and calc-alkaline magma composition and fractionally crystallized the melt starting above the liquidus temperature ranging from $1300^{\circ}$ to $885^{\circ} \mathrm{C}$ at $5^{\circ} \mathrm{C}$ increments at $0.6 \mathrm{kbar}$ (tholeiitic) and $1117^{\circ}$ to $762^{\circ} \mathrm{C}$ at $1 \mathrm{kbar}$ (calc-alkaline) (29). The initial oxygen fugacity of the tholeiitic and calc-alkaline melts was set to quartz-fayalitemagnetite (QFM) $-0.3(67)$ and $+0.6(17,68)$, respectively, and the melts evolved with no oxygen fugacity buffer and at constant pressure. The MELTS calculation stops at a point where 93 to $90 \%$ of the liquid has crystallized and the $\mathrm{SiO}_{2}$ content of the remaining melt has reached $\sim 68$ and $73 \mathrm{wt} \%$ for the tholeiitic and calc-alkaline magma, respectively.

For estimating the Ti isotopic composition of the MELTS model outputs, we follow procedures outlined in previous studies (29-31). For calc-alkaline magmas, we use the empirically derived relationship of the stable $\mathrm{Ti}$ isotopic fractionation factor of $\delta^{49} \mathrm{Ti}_{\text {melt-oxide }}=$ $0.23 \times 10^{6} / T^{2}$ from (29), where $10^{6} / T^{2}$ is in $\mathrm{K}^{-2}$. For tholeiitic magmas, we use fractionation factors from $(30,31)$ and a multiple linear regression analysis from (31) to obtain a Ti isotopic fractionation factor of $\delta^{49} \mathrm{Ti}_{\text {melt-oxide }}=\left(-0.5+0.017 \times\left[\mathrm{SiO}_{2}\right]\right) \times 10^{6} / T^{2}$, where $10^{6} / T^{2}$ is in $\mathrm{K}^{-2}$ and $\left[\mathrm{SiO}_{2}\right]$ is the $\mathrm{SiO}_{2}$ wt \% concentration of the melt. The $\mathrm{Ti}$ isotopic composition is modeled using a simple Rayleigh fractionation briefly outlined for tholeiitic magmas in (31).

\section{SUPPLEMENTARY MATERIALS}

Supplementary material for this article is available at http://advances.sciencemag.org/cgi/ content/full/6/50/eabc9959/DC1

\section{REFERENCES AND NOTES}

1. F. J. Vine, D. H. Matthews, Magnetic anomalies over oceanic ridges. Nature 199, 947-949 (1963).

2. A. Miyashiro, Volcanic rock series in island arcs and active continental margins. Am. J. Sci. 274, 321-355 (1974)

3. M. M. Zimmer, T. Plank, E. H. Hauri, G. M. Yogodzinski, P. Stelling, J. Larsen, B. Singer, B. Jicha, C. Mandeville, C. J. Nye, The role of water in generating the calc-alkaline trend: New volatile data for Aleutian magmas and a new tholeiitic index. J. Petrol. 51, 2411-2444 (2010).

4. S. R. Taylor, in Island Arcs, Deep Sea Trenches and Back-Arc Basins (AGU, 1977), pp. 325-335.

5. M. Brown, Duality of thermal regimes is the distinctive characteristic of plate tectonics since the Neoarchean. Geology 34, 961-964 (2006).

6. P. A. Cawood, A. Kröner, S. Pisarevesky, Precambrian plate tectonics: Criteria and evidence. Geol. Soc. Am. Today 16, 4-11 (2006).

7. W. B. Hamilton, Plate tectonics began in Neoproterozoic time, and plumes from deep mantle have never operated. Lithos 123, 1-20 (2011).

8. M. Hopkins, T. M. Harrison, C. E. Manning, Low heat flow inferred from $>4$ Gyr zircons suggests Hadean plate boundary interactions. Nature 456, 493-496 (2008).

9. T. Komiya, S. Maruyama, T. Masuda, S. Nohda, M. Hayashi, K. Okamoto, Plate tectonics at 3.8-3.7 Ga: Field evidence from the Isua accretionary complex, southern West Greenland. J. Geol. 107, 515-554 (1999).

10. A. P. Nutman, C. R. L. Friend, V. C. Bennett, Evidence for 3650-3600 Ma assembly of the northern end of the Itsaq Gneiss Complex, Greenland: Implication for early Archean tectonics. Tectonics 21, 1005 (2002).

11. S. B. Shirey, B. S. Kamber, M. J. Whitehouse, P. A. Mueller, A. R. Basu, in When Did Plate Tectonics Begin on Planet Earth?, K. C. Condie, V. Pease, Eds. (Geological Society of America, 2008), pp. 1-29.

12. R. J. Stern, Evidence from ophiolites, blueschists, and ultrahigh-pressure metamorphic terranes that the modern episode of subduction tectonics began in Neoproterozoic time. Geology 33, 557-560 (2005).

13. M. J. Van Kranendonk, R. H. Smithies, A. H. Hickman, D. C. Champion, Review: Secular tectonic evolution of Archean continental crust: Interplay between horizontal and vertical processes in the formation of the Pilbara Craton, Australia. Terra Nova 19, $1-38$ (2007).

14. H. Kuno, in Basalts: The Poldervaart Treatise on Rocks of Basaltic Composition, H. H. Hess, A. Poldervaart, Eds. (Interscience Publishers, 1968), pp. 623-688.

15. T. L. Grove, M. B. Baker, Phase equilibrium controls on the tholeiitic versus calc-alkaline differentiation trends. J. Geophys. Res. Solid Earth 89, 3253-3274 (1984).

16. T. W. Sisson, T. L. Grove, Experimental investigations of the role of $\mathrm{H}_{2} \mathrm{O}$ in calc-alkaline differentiation and subduction zone magmatism. Contrib. Mineral. Petrol. 113, 143-166 (1993).

17. K. A. Kelley, E. Cottrell, Water and the oxidation state of subduction zone magmas. Science 325, 605-607 (2009).

18. I. J. Parkinson, R. J. Arculus, The redox state of subduction zones: Insights from arcperidotites. Chem. Geol. 160, 409-423 (1999).

19. T. L. Grove, R. J. Kinzler, Petrogenesis of andesites. Annu. Rev. Earth Planet. Sci. 14, 417-454 (1986).

20. R. W. Carlson, M. Garçon, J. O'Neil, J. Reimink, H. Rizo, The nature of Earth's first crust. Chem. Geol. 530, 119321 (2019).

21. J. R. Reimink, T. Chacko, R. A. Stern, L. M. Heaman, Earth's earliest evolved crust generated in an Iceland-like setting. Nat. Geosci. 7, 529-533 (2014).

22. J. R. Reimink, T. Chacko, R. W. Carlson, S. B. Shirey, J. Liu, R. A. Stern, A. M. Bauer, D. G. Pearson, L. M. Heaman, Petrogenesis and tectonics of the Acasta Gneiss Complex derived from integrated petrology and ${ }^{142} \mathrm{Nd}$ and ${ }^{182} \mathrm{~W}$ extinct nuclide-geochemistry. Earth Planet. Sci. Lett. 494, 12-22 (2018).

23. J. R. Reimink, J. H. F. L. Davies, T. Chacko, R. A. Stern, L. M. Heaman, C. Sarkar, U. Schaltegger, R. A. Creaser, D. G. Pearson, No evidence for Hadean continental crust within Earth's oldest evolved rock unit. Nat. Geosci. 9, 777-780 (2016).

24. Y. Amelin, D.-C. Lee, A. N. Halliday, Early-middle archaean crustal evolution deduced from $\mathrm{Lu}-\mathrm{Hf}$ and $\mathrm{U}-\mathrm{Pb}$ isotopic studies of single zircon grains. Geochim. Cosmochim. Acta 64, 4205-4225 (2000).

25. T. lizuka, T. Komiya, S. P. Johnson, Y. Kon, S. Maruyama, T. Hirata, Reworking of Hadean crust in the Acasta gneisses, northwestern Canada: Evidence from in-situ Lu-Hf isotope analysis of zircon. Chem. Geol. 259, 230-239 (2009).

26. J. R. Reimink, T. Chacko, R. A. Stern, L. M. Heaman, The birth of a cratonic nucleus: Lithogeochemical evolution of the 4.02-2.94 Ga Acasta Gneiss Complex. Precambrian Res. 281, 453-472 (2016).

27. A. M. Bauer, C. M. Fisher, J. D. Vervoort, S. A. Bowring, Coupled zircon Lu-Hf and U-Pb isotopic analyses of the oldest terrestrial crust, the $>4.03 \mathrm{Ga}$ Acasta Gneiss Complex. Earth Planet. Sci. Lett. 458, 37-48 (2017). 
28. B. R. Frost, C. D. Frost, A geochemical classification for feldspathic igneous rocks. J. Petrol. 49, 1955-1969 (2008)

29. M.-A. Millet, N. Dauphas, N. D. Greber, K. W. Burton, C. W. Dale, B. Debret, C. G. Macpherson, G. M. Nowell, H. M. Williams, Titanium stable isotope investigation of magmatic processes on the Earth and Moon. Earth Planet. Sci. Lett. 449, 197-205 (2016).

30. Z. Deng, M. Chaussidon, P. Savage, F. Robert, R. Pik, F. Moynier, Titanium isotopes as a tracer for the plume or island arc affinity of felsic rocks. Proc. Natl. Acad. Sci. U.S.A. 116, 1132-1135 (2019).

31. A. C. Johnson, S. M. Aarons, N. Dauphas, N. X. Nie, H. Zeng, R. T. Helz, S. J. Romaniello, A. D. Anbar, Titanium isotopic fractionation in Kilauea Iki lava lake driven by oxide crystallization. Geochim. Cosmochim. Acta 264, 180-190 (2019).

32. L. Hoare, M. Klaver, N. S. Saji, J. Gillies, I. J. Parkinson, C. J. Lissenberg, M.-A. Millet, Melt chemistry and redox conditions control titanium isotope fractionation during magmatic differentiation. Geochim. Cosmochim. Acta 282, 38-54 (2020).

33. K. J. Orians, E. A. Boyle, K. W. Bruland, Dissolved titanium in the open ocean. Nature $\mathbf{3 4 8}$ 322-325 (1990).

34. G. E. Bebout, J. G. Ryan, W. P. Leeman, A. E. Bebout, Fractionation of trace elements by subduction-zone metamorphism-Effect of convergent-margin thermal evolution. Earth Planet. Sci. Lett. 171, 63-81 (1999).

35. J. N. Rubin, C. D. Henry, J. G. Price, The mobility of zirconium and other "immobile" elements during hydrothermal alteration. Chem. Geol. 110, 29-47 (1993).

36. N. D. Greber, N. Dauphas, A. Bekker, M. P. Ptáček, I. N. Bindeman, A. Hofmann, Titanium isotopic evidence for felsic crust and plate tectonics 3.5 billion years ago. Science 357, 1271-1274 (2017).

37. T. H. Druitt, D. M. Pyle, T. A. Mather, Santorini volcano and its plumbing system. Elements 15, 177-184 (2019).

38. X. Zhao, S. Tang, J. Li, H. Wang, R. Helz, B. Marsh, X. Zhu, H. Zhang, Titanium isotopic fractionation during magmatic differentiation. Contrib. Mineral. Petrol. 175, 67 (2020).

39. S.-Q. Li, E. Hegner, Y.-Z. Yang, J.-D. Wu, F. Chen, Age constraints on late Mesozoic lithospheric extension and origin of bimodal volcanic rocks from the Hailar basin NE China. Lithos 190-191, 204-219 (2014).

40. E. J. Chin, K. Shimizu, G. M. Bybee, M. E. Erdman, On the development of the calc-alkaline and tholeiitic magma series: A deep crustal cumulate perspective. Earth Planet. Sci. Lett. 482, 277-287 (2018).

41. J. R. Reimink, D. G. Pearson, S. B. Shirey, R. W. Carlson, J. W. F. Ketchum, Onset of new, progressive crustal growth in the central Slave craton at $3.55 \mathrm{Ga}$. Geochem. Perspect. Lett. 10, 8-13 (2019).

42. J.-F. Moyen, H. Martin, Forty years of TTG research. Lithos 148, 312-336 (2012).

43. C. O'Neill, A. Lenardic, L. Moresi, T. H. Torsvik, C.-T. A. Lee, Episodic Precambrian subduction. Earth Planet. Sci. Lett. 262, 552-562 (2007).

44. E. Sizova, T. Gerya, K. Stüwe, M. Brown, Generation of felsic crust in the Archean: A geodynamic modeling perspective. Precambrian Res. 271, 198-224 (2015).

45. E. Sizova, T. Gerya, M. Brown, L. L. Perchuk, Subduction styles in the Precambrian: Insight from numerical experiments. Lithos 116, 209-229 (2010).

46. P. G. Silver, M. D. Behn, Intermittent plate tectonics? Science 319, 85-88 (2008)

47. K. C. Condie, C. O'Neill, R. C. Aster, Evidence and implications for a widespread magmatic shutdown for 250 My on Earth. Earth Planet. Sci. Lett. 282, 294-298 (2009).

48. T. E. Johnson, N. J. Gardiner, K. Miljković, C. J. Spencer, C. L. Kirkland, P. A. Bland, H. Smithies, An impact melt origin for Earth's oldest known evolved rocks. Nat. Geosci. 11, 795-799 (2018).

49. Z. Deng, F. Moynier, P. A. Sossi, M. Chaussidon, Bridging the depleted MORB mantle and the continental crust using titanium isotopes. Geochem. Perspect. Lett. 9, 11-15 (2018).

50. T. V. Gerya, R. J. Stern, M. Baes, S. V. Sobolev, S. A. Whattam, Plate tectonics on the Earth triggered by plume-induced subduction initiation. Nature 527, 221-225 (2015).

51. N. D. Greber, N. Dauphas, I. S. Puchtel, B. A. Hofmann, N. T. Arndt, Titanium stable isotopic variations in chondrites, achondrites and lunar rocks. Geochim. Cosmochim. Acta 213, 534-552 (2017).

52. A. Roman, N. Arndt, Differentiated Archean oceanic crust: Its thermal structure, mechanical stability and a test of the sagduction hypothesis. Geochim. Cosmochim. Acta 278, 65-77 (2020).

53. A. B. Rozel, G. J. Golabek, C. Jain, P. J. Tackley, T. Gerya, Continental crust formation on early Earth controlled by intrusive magmatism. Nature 545, 332-335 (2017).

54. A. M. Bauer, J. R. Reimink, T. Chacko, B. J. Foley, S. B. Shirey, D. G. Pearson, Hafnium isotopes in zircons document the gradual onset of mobile-lid tectonics. Geochem. Perspect. Lett. 14, 1-6 (2020).

55. W. J. Collins, S. D. Beams, A. J. R. White, B. W. Chappell, Nature and origin of A-type granites with particular reference to Southeastern Australia. Contrib. Mineral. Petrol. 80, 189-200 (1982).

56. J. D. Clemens, J. R. Holloway, A. J. R. White, Origin of an A-type granite: Experimental constraints. Am. Mineral. 71, 317-324 (1986).
57. J. B. Whalen, K. L. Currie, B. W. Chappell, A-type granites: Geochemical characteristics, discrimination and petrogenesis. Contrib. Mineral. Petrol. 95, 407-419 (1987).

58. R. F. Martin, A-type granites of crustal origin ultimately result from open-system fenitization-type reactions in an extensional environment. Lithos 91, 125-136 (2006).

59. M. C. Loiselle, D. R. Wones, Characteristics of anorogenic granites. Geol. Soc. Am. Abstr. Prog. 11, 468 (1979).

60. S. P. Turner, J. D. Foden, R. S. Morrison, Derivation of some A-type magmas by fractionation of basaltic magma: An example from the Padthaway Ridge, South Australia. Lithos 28, 151-179 (1992).

61. J. L. Anderson, in Proterozoic Geology: Selected Papers from an International Proterozoic Symposium, J. G. Medaris Jr., C. W. Byers, D. M. Mickelson, W. C. Shanks, Eds. (Geological Society of America Memoir, 1983), vol. 161.

62. R. A. Creaser, R. C. Price, R. J. Wormald, A-type granites revisited: Assessment of a residual-srouce model. Geology 19, 163-166 (1991).

63. M.-A. Millet, N. Dauphas, Ultra-precise titanium stable isotope measurements by double-spike high resolution MC-ICP-MS. J. Anal. At. Spectrom 29, 1444-1458 (2014).

64. J. Zhang, N. Dauphas, A. M. Davis, A. Pourmand, A new method for MC-ICPMS measurement of titanium isotopic composition: Identification of correlated isotope anomalies in meteorites. J. Anal. At. Spectrom 26, 2197-2205 (2011)

65. N. Dauphas, A. Pourmand, F.-Z. Teng, Routine isotopic analysis of iron by HR-MC-ICPMS: How precise and how accurate? Chem. Geol. 267, 175-184 (2009).

66. N. Dauphas, P. E. Janney, R. A. Mendybaev, M. Wadhwa, F. M. Richter, A. M. Davis, M. van Zuilen, R. Hines, C. N. Foley, Chromatographic separation and multicollectionICPMS analysis of iron. Investigating mass-dependent and independent isotope effects. Anal. Chem. 76, 5855-5563 (2004).

67. P. J. Wallace, I. S. E. Carmichael, Sulfur in basaltic magmas. Geochim. Cosmochim. Acta 56, 1863-1874 (1992).

68. N. Métrich, M. Bonnin-Mosbah, B. Menez, L. Galoisy, Presence of sulfite (SIV) in arc magmas: Implications for volcanic sulfur emissions. Geophys. Res. Lett. 29, 1-33 (2002).

69. P. A. Sossi, J. D. Foden, G. P. Halverson, Redox-controlled iron isotope fractionation during magmatic differentiation: An example from the Red Hill intrusion, S. Tasmania. Contrib. Mineral. Petrol. 164, 757-772 (2012).

70. N. Dauphas, M. Roskosz, E. E. Alp, D. R. Neuville, M. Y. Hu, C. K. Sio, F. L. H. Tissot, J. Zhao, L. Tissandier, E. Médard, C. Cordier, Magma redox and structural controls on iron isotope variations in Earth's mantle and crust. Earth Planet. Sci. Lett. 398, 127-140 (2014).

71. M. Roskosz, C. K. I. Sio, N. Dauphas, W. Bi, F. L. H. Tissot, M. Y. Hu, J. Zhao, E. E. Alp, Spinel-olivine-pyroxene equilibrium iron isotopic fractionation and applications to natural peridotites. Geochim. Cosmochim. Acta 169, 184-199 (2015).

72. S. A. Bowring, I. S. Williams, W. Compston, $3.96 \mathrm{Ga}$ gneisses from the Slave province, Northwest Territories, Canada. Geology 17, 971-975 (1989).

73. S. A. Bowring, I. S. Williams, Priscoan (4.00-4.03 Ga) orthogneisses from northwestern Canada. Contrib. Mineral. Petrol. 134, 3-16 (1999).

74. R. Stern, W. Bleeker, Age of the world's oldest rocks refined using Canada's SHRIMP: The Acasta Gneiss Complex, Northwest Territories, Canada. Geoscience Canada 25, 27-31 (1998).

75. A. S. G. Roth, B. Bourdon, S. J. Mojzsis, J. F. Rudge, M. Guitreau, J. Blichert-Toft, Combined ${ }^{147,146} \mathrm{Sm}-{ }^{143,142} \mathrm{Nd}$ constraints on the longevity and residence time of early terrestrial crust. Geochem. Geophys. Geosyst. 15, (2014)

76. M. Guitreau, J. Blichert-Toft, S. J. Mojzsis, A. S. G. Roth, B. Bourdon, N. L. Cates, W. Bleeker, Lu-Hf isotope systematics of the Hadean-Eoarchean Acasta Gneiss Complex (Northwest Territories, Canada). Geochim. Cosmochim. Acta 135, 251-269 (2014).

77. Y. Amelin, D.-C. Lee, A. N. Halliday, R. T. Pidgeon, Nature of the Earth's earliest crust from hafnium isotopes in single detrital zircons. Nature 399, 252-255 (1999).

78. T. lizuka, T. Hirata, Improvements of precision and accuracy in in situ $\mathrm{Hf}$ isotope microanalysis of zircon using the laser ablation-MC-ICPMS technique. Chem. Geol. 220, 121-137 (2005).

79. R. H. Smithies, The Archaean tonalite-trondhjemite-granodiorite (TTG) series is not an analogue of Cenozoic adakite. Earth Planet. Sci. Lett. 182, 115-125 (2000).

80. M. Telus, N. Dauphas, F. Moynier, F. L. H. Tissot, F.-Z. Teng, P. I. Nabelek, P. R. Craddock, L. A. Groat, Iron, zinc, magnesium and uranium isotopic fractionation during continental crust differentiation: The tale from migmatites, granitoids, and pegmatites. Geochim. Cosmochim. Acta 97, 247-265 (2012).

81. K. Kreissig, T. F. Nägler, J. D. Kramers, D. D. Reenen, C. A. Smit, An isotopic and geochemical study of the northern Kaapvaal Craton and the Southern Marginal Zone of the Limpopo Belt: Are they juxtaposed terranes? Lithos 50, 1-25 (2000).

82. R. Batiza, Y. Niu, Petrology and magma chamber processes at the East Pacific Rise 9³0'N. J. Geophys. Res. Solid Earth 97, 6779-6797 (1992).

83. H. Puchelt, R. Emmermann, Petrogenetic implications of tholeiitic basalt glasses from the East Pacific Rise and the Galápagos Spreading Center. Chem. Geol. 38, 39-56 (1983)

84. S. Escrig, F. Capmas, B. Dupré, C. J. Allègre, Osmium isotopic constraints on the nature of the DUPAL anomaly from Indian mid-ocean-ridge basalts. Nature 431, 59-63 (2004). 
85. W. Yi, A. N. Halliday, J. C. Alt, D.-C. Lee, M. Rehkämper, M. O. Garcia, C. H. Langmuir, Y. Su, Cadmium, indium, tin, tellurium, and sulfur in oceanic basalts: Implications for chalcophile element fractionation in the Earth. J. Geophys. Res. Solid Earth 105 18927-18948 (2000)

86. P. E. Baker, F. Buckley, J. G. Holland, Petrology and geochemistry of easter island. Contrib. Mineral. Petrol. 44, 85-100 (1974).

87. M.-A. Millet, R. Doucelance, P. Schiano, K. David, C. Bosq, Mantle plume heterogeneity versus shallow-level interactions: A case study, the São Nicolau Island, Cape Verde archipelago. J. Volcanol. Geotherm. Res. 176, 265-276 (2008).

88. S. Turner, C. Hawkesworth, N. Rogers, P. King, U-Th isotope disequilibria and ocean island basalt generation in the Azores. Chem. Geol. 139, 145-164 (1997).

89. M.-A. Millet, R. Doucelance, J. A. Baker, P. Schiano, Reconsidering the origins of isotopic variations in Ocean Island Basalts: Insights from fine-scale study of São Jorge Island, Azores archipelago. Chem. Geol. 265, 289-302 (2009).

90. R. T. Helz, H. K. Kirschenbaum, J. W. Marinenko, R. Qian, Whole-rock analyses of core samples from the 1967, 1975, 1979 and 1981 drillings of Kilauea Iki laba lake, Hawaii (U.S. Geological Survey Professional Paper, Open-File Report 94-684, 1994).

91. K. J. Murata, D. H. Richter, Chemistry of the lavas of the 1959-60 eruption of Kilauea Volcano, Hawaii (U.S. Geological Survey Professional Paper, Report no. 537-A, 1966).

92. F. A. Frey, M. O. Garcia, M. F. Roden, Geochemical characteristics of Koolau Volcano: Implications of intershield geochemical differences among Hawaiian volcanoes. Geochim. Cosmochim. Acta 58, 1441-1462 (1994).

93. P. S. Savage, R. B. Georg, H. M. Williams, K. W. Burton, A. N. Halliday, Silicon isotope fractionation during magmatic differentiation. Geochim. Cosmochim. Acta 75, 6124-6139 (2011).

94. R. Pik, B. Marty, D. R. Hilton, How many mantle plumes in Africa? The geochemical point of view. Chem. Geol. 226, 100-114 (2006).

95. L. Field, A. Calvert, G. Yirgu, Magmatic history of Dabbahu, a composite volcano in the Afar Rift, Ethiopia. Geol. Soc. Am. Bull. 125, 128-147 (2013).

96. K. J. Chamberlin, J. Barclay, K. J. Preece, R. J. Brown, J. P. Davidson, Lower crustal heterogeneity and fractional crystallization control evolution of small-volume magma batches at ocean island volcanoes (Ascension Island, South Atlantic). J. Petrol. 60, 1489-1522 (2019).

97. J. Barling, "The petrogenesis of the Newer Lavas of Heard Island, southern Indian Ocean," thesis, Monash University (1990).

98. J. Barling, S. L. Golstein, I. A. Nicholls, Geochemistry of Heard Island (southern Indian Ocean): Characterization of an enriched mantle component and implications for enrichment of the sub-Indian Ocean mantle. J. Petrol. 35, 1017-1053 (1994).

99. D. A. Clague, D. W. Caress, B. M. Dreyer, L. Lundsten, J. B. Paduan, R. A. Portner, R. Spelz-Madero, J. A. Bowles, P. R. Castillo, R. Guardado-France, M. L. Saout, J. F. Martin, M. A. Santa Rosa-del Río, R. A. Zierenberg, Geology of the Alarcon rise, Southern Gulf of California. Geochem. Geophys. Geosyst. 19, 807-837 (2018).

100. C. Timm, I. J. Graham, C. E. J. de Ronde, M. I. Leybourne, J. Woodhead, Geochemical evolution of Monowai volcanic center: New insights into the northern Kermadec arc subduction system, SW Pacific. Geochem. Geophys. Geosyst. 12, Q0AF01 (2011).

101. S. Dempsey, "Geochemistry of volcanic rocks from the Sunda Arc," thesis, Durham University (2013).

102. D. Peters, T. Pettke, Evaluation of major to ultra trace element bulk rock chemical analysis of nanoparticulate pressed powder pellets by LA-ICP-MS. Geostand. Geoanal. Res. 41, 5-28 (2017).

103. M. Klaver, G. R. Davies, P. Z. Vroon, Subslab mantle of African provenance infiltrating the Aegean mantle wedge. Geology 44, 367-370 (2016).

104. M. Klaver, S. Carey, P. Nomikou, I. Smet, A. Godelitsas, P. Vroon, A distinct source and differentiation history for Kolumbo submarine volcano, Santorini volcanic field, Aegean arc. Geochem. Geophys. Geosyst. 17, 3254-3273 (2016).

105. M. Klaver, "Dynamics of magma generation and differentiation in the central-eastern Aegean arc: A geochemical and petrological study of Quaternary arc volcanism in Greece," thesis, Vrije Universiteit (2016).

106. L.-K. Sha, B. W. Chappell, Apatite chemical composition, determined by electron microprobe and laser-ablation inductively coupled plasma mass spectrometry, as a probe into granite petrogenesis. Geochim. Cosmochim. Acta 63, 3861-3881 (1999).

107. B. W. Chappell, Source rocks of I-type and S-type granites in the Lachlan Fold Belt, Southeastern Australia. Philos. Trans. A Math. Phys. Eng. Sci. 310, 693-707 (1984).

108. B. W. Chappell, A. J. R. White, The Cowra Granodiorite and Its Enclaves. IAVCEI Canberra Excursion Guide (Australian Geological Survey Organisation, 1993).

109. R. Hine, I. S. Williams, B. W. Chappell, A. J. R. White, Contrasts between I- and S-type granitoids of the Koscuisko Batholith. J. Geol. Soc. Aus. 25, 219-234 (1978).
110. B. W. Chappell, A. J. R. White, l- and S-type granites in the Lachlan Fold Belt. Phil. Trans. R. Soc. Edinb. Earth Sci. 83, 1-26 (1992).

111. P. I. King, A. J. R. White, B. W. Chappell, C. M. Allen, Characterization and origin of aluminous A type granites of the Lachlan Fold Belt, Southeastern Australia. J. Petrol. 38, 371-391 (1997).

112. I. S. Puchtel, R. J. Walker, M. Touboul, E. G. Nisbet, G. R. Byerly, Insights into early Earth from the Pt-Re-Os isotope and highly siderophile element abundance systematics of Barberton komatiites. Geochim. Cosmochim. Acta 125, 394-413 (2014).

113. I. S. Puchtel, J. Blichert-Toft, M. Touboul, R. J. Walker, G. R. Byerly, E. G. Nisbet, C. R. Anhaeusser, Insights into early Earth from Barberton komatiites: Evidence from lithophile isotope and trace element systematics. Geochim. Cosmochim. Acta 108, 63-90 (2013).

114. I. S. Puchtel, J. Blichert-Toft, M. Touboul, M. F. Horan, R. J. Walker, The coupled ${ }^{182} \mathrm{~W}^{142} \mathrm{Nd}$ record of early terrestrial mantle differentiation. Geochem. Geophys. Geosyst. 17, 2168-2193 (2016).

115. Y. Lahaye, N. Arndt, Alteration of a komatiite flow from Alexo, Ontario, Canada. J. Petrol. 37, 1261-1284 (1996)

116. N. Dauphas, F.-Z. Teng, N. T. Arndt, Magnesium and iron isotopes in 2.7 Ga Alexo komatiites: Mantle signatures, no evidence for Soret diffusion, and identification of diffusive transport in zoned olivine. Geochim. Cosmochim. Acta 74, 3274-3291 (2014).

117. I. S. Puchtel, R. J. Walker, A. D. Brandon, E. G. Nisbet, Pt-Re-Os and Sm-Nd isotope and HSE and REE systematics of the $2.7 \mathrm{Ga}$ Belingwe and Abitibi komatiites. Geochim. Cosmochim. Acta 73, 6367-6389 (2009).

118. P. A. Sossi, S. M. Eggins, R. W. Nesbitt, O. Nebel, J. M. Hergt, I. H. Campbell, H. S. C. O'Neill, M. Van Kranendonk, D. R. Davies, Petrogenesis and geochemistry of Archean komatiites. J. Petrol. 57, 147-184 (2016).

119. P. R. Craddock, N. Dauphas, Iron isotopic compositions of geological reference materials and chondrites. Geostand. Geoanal. Res. 35, 101-123 (2011).

120. P. I. Nabelek, C. Russ-Nabelek, J. R. Denison, The generation and crystallization conditions of the Proterozoic Harney Peak Leucogranite, Black Hills, South Dakota, USA: Petrologic and geochemical constraints. Contrib. Mineral. Petrol. 110, 173-191 (1992).

121. R. J. Walker, "Origin of the Tin Mountain Pegmatites, Black Hills, South Dakota," thesis, State University of New York at Stony Brook (1984).

122. R. J. Walker, G. N. Hanson, J. J. Papike, Trace element constraints on pegmatite genesis: Tin Mountain Pegmatite, Black Hills, South Dakota. Contrib. Mineral. Petrol. 101, 290-300 (1989).

123. L. A. Groat, T. Mulja, M. H. F. Mauthner, T. S. Ercit, M. Raudsepp, R. A. Gault, H. A. Rollo, Geology and mineralogy of the little nahanni rare-element granitic pegmatites, northwest territories. Can. Mineral. 41, 139-160 (2003).

124. P. I. Nabelek, Trace element distribution among rock- forming minerals in Black Hills migmatites, South Dakota; a case for solid-state equilibrium. Am. Mineral. 84, 1256-1269 (1999).

125. I. McDougall, Differentiation of the Tasmanian dolerites: Red Hill dolerite-granophyre association. Geol. Soc. Am. Bull. 73, 279-316 (1962).

Acknowledgments: We thank the editor, an anonymous reviewer, and M. Harrison for their comments that greatly improved this manuscript. Discussions with N.X. Nie, J. Hu, C. Chen, H. Zeng, A. Johnson, K. Prissel, and E. Chin were greatly appreciated. Funding: This work was funded by the Ford Foundation Fellowship awarded to S.M.A., NASA grants NNX17AE86G (LARS) and NNX17AE87G (Emerging Worlds) to N.D., and NASA grant 80NSSC17K0744 (Habitable Worlds) to N.D. and A.W.H. N.D.G. acknowledges funding from the Swiss National Science Foundation (project number 181172). Author contributions: S.M.A., J.R.R., and N.D.G. designed the study. S.M.A., A.W.H., and Z.Z. performed the measurements. S.M.A. wrote the first draft of the manuscript, which was edited by J.R.R., N.D.G., A.W.H., Z.Z., and N.D. Competing interests: The authors declare that they have no competing interests. Data and materials availability: All data needed to evaluate the conclusions in the paper are present in the paper and/or the Supplementary Materials. Additional data related to this paper may be requested from the authors.

\section{Submitted 26 May 2020}

Accepted 23 October 2020

Published 9 December 2020

10.1126/sciadv.abc9959

Citation: S. M. Aarons, J. R. Reimink, N. D. Greber, A. W. Heard, Z. Zhang, N. Dauphas, Titanium isotopes constrain a magmatic transition at the Hadean-Archean boundary in the Acasta Gneiss Complex. Sci. Adv. 6, eabc9959 (2020). 


\section{ScienceAdvances}

\section{Titanium isotopes constrain a magmatic transition at the Hadean-Archean boundary in the Acasta Gneiss Complex}

Sarah M. Aarons, Jesse R. Reimink, Nicolas D. Greber, Andy W. Heard, Zhe Zhang and Nicolas Dauphas

Sci Adv 6 (50), eabc9959.

DOI: $10.1126 /$ sciadv.abc9959

ARTICLE TOOLS

SUPPLEMENTARY

MATERIALS

REFERENCES

PERMISSIONS http://advances.sciencemag.org/content/6/50/eabc9959

http://advances.sciencemag.org/content/suppl/2020/12/07/6.50.eabc9959.DC1

This article cites 113 articles, 15 of which you can access for free http://advances.sciencemag.org/content/6/50/eabc9959\#BIBL

http://www.sciencemag.org/help/reprints-and-permissions

Science Advances (ISSN 2375-2548) is published by the American Association for the Advancement of Science, 1200 New York Avenue NW, Washington, DC 20005. The title Science Advances is a registered trademark of AAAS.

Copyright ( 2020 The Authors, some rights reserved; exclusive licensee American Association for the Advancement of Science. No claim to original U.S. Government Works. Distributed under a Creative Commons Attribution NonCommercial License 4.0 (CC BY-NC). 